\title{
Enhancement of Phytochemical Compounds Using Biotic and Abiotic Elicitors in Purple Coneflower (Echinacea purpurea L.)
}

\author{
Muhammed Akif Açikgöz'1, Tarık Yarılgaç², Şevket Metin Kara ${ }^{{ }^{\star}}$ \\ ${ }^{1}$ Department of Field Crops, Faculty of Agriculture, Ordu University, Ordu, TURKEY. \\ ${ }^{2}$ Department of Horticulture, Faculty of Horticulture, Ordu University, Ordu, TURKEY.
}

\begin{abstract}
Background: Phytochemicals also known secondary metabolites, naturally occurring in medicinal and aromatic plants, are of considerable importance for plant survival and human health. Objective: The objective of this study was to increase accumulation of caffeic acid and alkamide, using biotic and abiotic stresses conditions driving cell defense systems, in cell suspension cultures in purple coneflower (Echinacea purpurea L.). Methods: As biotic and abiotic elicitors, yeast extract $\left(0,25,50\right.$ and $\left.100 \mathrm{mg} \mathrm{l}^{-1}\right)$, chitosan $\left(0,25,50\right.$ and $\left.100 \mathrm{mg} \mathrm{l}^{-1}\right)$, sorbitol $\left(0,5,25\right.$ and $\left.50 \mathrm{~g} \mathrm{l}^{-1}\right)$, cadmium chloride $(0,5,25$ and $50 \mu \mathrm{M})$ and silver nitrate $(0,5,25$ and $50 \mu \mathrm{M})$ solutions were used in an eight-day cell culture. The cells were daily harvested up to the third day of the culture in cadmium chloride and silver nitrate, whereas up to the seventh day of the culture in the other applications. Alkamide and caffeic acid contents in harvested cells were determined using GC-MS device. Results: The contents of alkamide and caffeic acid, as compared to the control, increased by 1.3 and 0.5 times with $50 \mathrm{mg} \mathrm{l}^{-1}$ yeast application. In the applications of $25 \mathrm{~g} \mathrm{l}^{-1}$ sorbitol and $100 \mathrm{mg} \mathrm{l}^{-1}$ chitosan, alkamide content increased by 0.8 and 1.5 fold, but the amounts of caffeic acid increased by 2.5 and 3.1 fold, in comparison to the control culture. The highest amounts of alkamide in cadmium chloride and silver nitrate (105 and $127 \mu \mathrm{g} \mathrm{g}^{-1} \mathrm{dw}$, respectively) were obtained after $24 \mathrm{~h}$ from starting culture, while caffeic acid content reached its highest value $\left(27\right.$ and $38 \mu \mathrm{g} \mathrm{g}^{-1}$ $\mathrm{dw}$, respectively) after $72 \mathrm{~h}$. Conclusion: This study indicated that biotic and abiotic stress factors, by driving cell defense systems, had a great potential for increasing caffeic acid and alkamide in vitro conditions in purple coneflower.
\end{abstract}

Key words: Alkamide, Caffeic acid, Callus culture, Secondary metabolites.

\section{INTRODUCTION}

Phytochemicals, naturally produced in some high-structured plants and important for human health, are produced in a great number and diversity in plants. The plants are affected positively or negatively from the ecological conditions of their natural habitat. In this case, the produced secondary metabolites are inhibited having a certain level of quality and standard. Furthermore, the production of plants with known classical methods and also the production of secondary metabolites from these plants is rather costly and time consuming compared to cell cultures. Therefore, tissue culture techniques in the production of secondary metabolites are frequently used. Cell suspension culture, one of these techniques, allow to produce secondary metabolites in specific qualities and standards and to obtain new compounds not being in the main plant as independently of geographical, seasonal and environmental factors. Most phytochemicals such as ginseng, slymarine, paclitaxel, plumbagin and puerarin are produced using this technique. Echinacea purpurea L., with the origin of North America, is a species having antibacterial, antiviral and antifungal properties. Naturally occurring
Submission Date: 30-08-2017; Revision Date: 17-11-2017; Accepted Date: 23-11-2017

DOI: $10.5530 / i j p e r .52 .4 s .90$ Correspondence: Şevket Metin Kara, Ordu University, Faculty of Agriculture, Department of Field Crops, 52200-Ordu, TURKEY.

Phone: (+90) 5327938115 E-mail: smkara58@hotmail. com

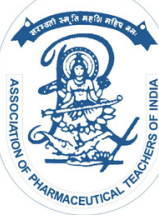

www.ijper.org 
certain important phytochemicals such as caffeic acid and alkamide have made this species as one of the most studied plant species in recent years. ${ }^{1-3}$ The effect of various elicitors (lighting period, light intensity, U.V B and $\mathrm{C}$ rays, jasmonic acid, methyl jasmonate, salicylic acid and incubation temperature and duration) on caffeic acid and alkamide accumulation have carried out in Echinacea species until today, using adventitious root cultures in Echinacea species. At the end of these studies, some appropriate protocols for the production of these valuable phytochemicals with bioreactors have been developed. ${ }^{4-9}$ In cell suspension cultures, however, the effects of elicitors on the accumulation of phytochemicals have not been sufficiently investigated. The objective of this study is to enhance biosynthesis of caffeic acid and alkamide in cell suspension cultures. For this reason, various elicitors (yeast extract, chitosan, silver nitrate, cadmium chloride and sorbitol) were applied to cell cultures and their effects on the accumulation of phytochemicals were studied.

\section{MATERIAL AND METHOD}

In the study, coneflower (Echinacea purpurea L.) seeds were used as plant material. The seeds were germinated in a medium containing $2.0 \mathrm{mg} / 1 \mathrm{BAP}+0.01 \mathrm{mg} / \mathrm{l} \mathrm{IBA}$ $+2.0 \mathrm{mg} / 1 \mathrm{GA}_{3}$ and sterilized plantlets were obtained. The leaf and stem explants of these plantlets were cultured in MS and B5 media with different combinations of plant growth regulators (using 2, 4-D x BAP and NAA $x$ KIN combinations) at $25^{\circ} \mathrm{C}(16 \mathrm{~h} \mathrm{light} / 8 \mathrm{~h}$ darkness). Cell suspension cultures were generated from B5 medium supplemented with $1 \mathrm{mg} / \mathrm{l} \mathrm{BAP}+2 \mathrm{mg} / \mathrm{l}$ NAA hormone combination in which stem explant was used. Afterward, the concentrations of 0 (control) -25 , 50 and $100 \mathrm{mg} \mathrm{l-1}$ of yeast extract and chitosan were applied to cell cultures, as biotic elicitors. As abiotic elicitors, sorbitol with the doses of 0,5,25 and $50 \mathrm{~g} \mathrm{l}^{-1}$, cadmium chloride $\left(\mathrm{CdCI}_{2}\right)$ and silver nitrate $\left(\mathrm{AgNO}_{3}\right)$ with the doses of $0,5,25$ and $50 \mu \mathrm{M}$ were applied to cell cultures. In the first three applications, the samples were harvested with $24 \mathrm{~h}$ intervals from the first day (after $24 \mathrm{~h}$ ) to the $8^{\text {th }}$ day, but the samples were harvested with $24 \mathrm{~h}$ intervals from the first day (after $24 \mathrm{~h}$ ) to the $4^{\text {th }}$ day in the last two applications. Each of the applications was carried out with three replicates in 8-day cell cultures. All applications with completed sampling were filtered and washed in a sterile cabinet to be used in caffeic acid and alkamide analysis and stored in deep freeze $\left(-20^{\circ} \mathrm{C}\right)$ until extraction. Content of caffeic acid and alkamide was determined using GC-MS device. For headspace analysis, Shimadzu QP2010 ultra waC-MS device and capillary colon separation was done with RTX-5M 30 m. The device was first given a standard of compounds and then mass fragments and retention time were determined. Calibration curves of the compounds were then drawn and the amount of the samples was determined as $\mu \mathrm{g} / \mathrm{g}$. In statistical evaluation, a two-way analysis of variance was used. The differences among the means were determined by the Tukey test and the results were given as mean \pm standard error. A 5\% significance level was used in calculations and interpretations as well.

\section{RESULTS AND DISCUSSION}

In all elicitor applications, the amount of caffeic acid and alkamide content increased according to the concentration used and the time spent. At the concentration of $50 \mathrm{mg} / \mathrm{l}$ of the yeast extract, the amount of caffeic acid increased from $7.1 \mu \mathrm{g} / \mathrm{g}$ to $10.8 \mu \mathrm{g} / \mathrm{g}$ at the end of the 5 th day, increasing by $52 \%$ over the control group. At the same concentration, alkamide content raised from $24.2 \mu \mathrm{g} / \mathrm{g}$ to $55.7 \mu \mathrm{g} / \mathrm{g}$, increasing by 1.33 fold (Table 1 ). On the other hand, as shown in Table 2, chitosan doses increased accumulation of caffeic acid continuously starting at the $1^{\text {st }}$ day and the highest caffeic acid of $30.2 \mu \mathrm{g} / \mathrm{g}$ was attained with $100 \mathrm{mg} / \mathrm{l}$ chitosan dose at the end of the $7^{\text {th }}$ day. At the same dose, alkamide content increased continuously from the $1^{\text {st }}$ day and at the end of the $6^{\text {th }}$ day it reached up to $60.2 \mu \mathrm{g} / \mathrm{g}$, as compared to the control. In the application of $25 \mathrm{~g} / 1$ of sorbitol solution, the amount of caffeic acid, compared to control culture, increased from $7.37 \mu \mathrm{g} / \mathrm{g}$ to $24.37 \mu \mathrm{g} / \mathrm{g}$ at the end of the $7^{\text {th }}$ day. Alkamide content of $23.7 \mu \mathrm{g} / \mathrm{g}$ in the initial culture increased to the level of $42.66 \mu \mathrm{g} / \mathrm{g}$ at the end of the $3^{\text {rd }}$ day, at the same concentration (Table 3 ). Cadmium chloride application of $25 \mu \mathrm{M}$ produced the highest caffeic acid $(27 \mu \mathrm{g} / \mathrm{g})$ and alkamide content $(105 \mu \mathrm{g} / \mathrm{g})$ after 72 and $24 \mathrm{~h}$ from the application, respectively (Table 4$)$. The highest caffeic acid $(38 \mu \mathrm{g} / \mathrm{g})$ was obtained after $72 \mathrm{~h}$ from the application of $50 \mu \mathrm{M}$ silver nitrate. At the same concentration, alkamide content reached its highest value of $127 \mu \mathrm{g} / \mathrm{g}$ after $24 \mathrm{~h}$ from the application (Table 5). The caffeic acid and alkamide accumulation reached the highest value at $50 \mathrm{mg} / 1$ doses in yeast elicitor applications.

There are a number of studies indicating that the yeast elicitors promote the accumulation of phytochemicals, while the doses used rather vary according to plant species. For example, the accumulation of tanshinone terpene was promoted the most by $100 \mathrm{mg} / \mathrm{l}$ yeast application, while its accumulation in another species was promoted the most by $200 \mathrm{mg} / 1$ yeast application. ${ }^{10-13}$ On the other hand, the present study revealed that the 


\begin{tabular}{|c|c|c|c|c|c|c|c|c|}
\hline \multirow[b]{3}{*}{ s.t. } & \multicolumn{8}{|c|}{ Yeast extract $(\mathrm{mg} / \mathrm{l})$} \\
\hline & \multicolumn{4}{|c|}{ Caffeic acid $(\mu \mathrm{g} / \mathrm{g})$} & \multicolumn{4}{|c|}{ Alkamide $(\mu \mathrm{g} / \mathrm{g})$} \\
\hline & 0 & 25 & 50 & 100 & 0 & 25 & 50 & 100 \\
\hline 1.d & $6.8 \pm 0.3 n^{* *}$ & $7.8 \pm 0.2 \mathrm{j}-\mathrm{m}$ & $8.4 \pm 0.3 b-j$ & $9.7 \pm 0.1 \mathrm{~b}-\mathrm{e}$ & $23 \pm 0.1 \mathrm{~m}^{* *}$ & $24 \pm 0.3 \mathrm{klm}$ & $24 \pm 0.2 \mathrm{j}-\mathrm{m}$ & $23 \pm 0.5 \mathrm{~m}$ \\
\hline 2.d & $7.0 \pm 0.4 \mathrm{mn}$ & $7.9 \pm 0.2 \mathrm{j}-\mathrm{m}$ & $8.8 \pm 0.2 \mathrm{e}-1$ & $9.7 \pm 0.2 \mathrm{~b}-\mathrm{e}$ & $23.4 \pm 0.1 \mathrm{Im}$ & $32.4 \pm 0.3 \mathrm{gh}$ & $37.47 \pm 0.7 d$ & $28.1 \pm 0.31$ \\
\hline 3.d & $7.4 \pm 0.11 \mathrm{mn}$ & $8.4 \pm 0.2 \mathrm{~h}-\mathrm{k}$ & $9.1 \pm 0.1 d-h$ & $9.5 \pm 0.2 c-f$ & $23.70 \pm 0.1 \mathrm{klm}$ & $32.9 \pm 0.4 \mathrm{fg}$ & $46.6 \pm 0.5 d$ & $34.4 \pm 0.3 e$ \\
\hline $4 . d$ & $7.4 \pm 0.11-n$ & $8.9 \pm 0.2 \mathrm{e}-1$ & $9.8 \pm 0.3 \mathrm{bcd}$ & $9.6 \pm 0.2 b-e$ & $24.2 \pm 0.4 \mathrm{j}-\mathrm{m}$ & $33.7 \pm 0.2 \mathrm{ef}$ & $50.37 \pm 0.7 b$ & $38.2 \pm 0.3 d$ \\
\hline $5 . d$ & $7.1 \pm 0.5 \mathrm{mn}$ & $9.6 \pm 0.2 \mathrm{~b}-\mathrm{e}$ & $10.8 \pm 0.5 a$ & $10.4 \pm 0.4 \mathrm{ab}$ & $24.2 \pm 0.1 \mathrm{j}-\mathrm{m}$ & $33.1 \pm 0.1 \mathrm{fg}$ & $55.7 \pm 0.2 a$ & $31.3 \pm 0.5 \mathrm{~h}$ \\
\hline $6 . d$ & $7.6 \pm 0.2 \mathrm{k}-\mathrm{n}$ & $8.3 \pm 0.4 \mathrm{~h}-\mathrm{k}$ & $9.9 \pm 0.3 \mathrm{bc}$ & $9.2 \pm 0.3 c-g$ & $24.1 \pm 0.4 \mathrm{klm}$ & $33.3 \pm 0.1 \mathrm{efg}$ & $51.4 \pm 0.3 b$ & $21.50 \pm 0.8 m$ \\
\hline 7.d & $7.3 \pm 0.21 \mathrm{mn}$ & $8.3 \pm 0.6 \mathrm{~h}-\mathrm{k}$ & $9.6 \pm 0.3 b-f$ & $9.6 \pm 0.3 b-f$ & $23.4 \pm 0.61 \mathrm{~m}$ & $32.6 \pm 0.35 f g$ & $51.1 \pm 0.8 b$ & $17.4 \pm 0.80$ \\
\hline
\end{tabular}

$* *$ : The differences among the means without common letter are significant $(p<0.01)$; s. t: sampling time; $d$ : day

\begin{tabular}{|c|c|c|c|c|c|c|c|c|}
\hline \multirow{3}{*}{ s.t. } & \multicolumn{8}{|c|}{ Chitosan (mg/l) } \\
\hline & \multicolumn{4}{|c|}{ Caffeic acid $(\mu \mathrm{g} / \mathrm{g})$} & \multicolumn{4}{|c|}{ Alkamide $(\mu \mathrm{g} / \mathrm{g})$} \\
\hline & 0 & 25 & 50 & 100 & 0 & 25 & 50 & 100 \\
\hline 1.d & $6.8 \pm 0.30^{* *}$ & $10.3 \pm 0.7 n$ & $14.9 \pm 0.41$ & $17.7 \pm 0.4 \mathrm{gh}$ & $23.4 \pm 0.1 \mathrm{k}^{* *}$ & $23.8 \pm 0.1 \mathrm{k}$ & $24.3 \pm 0.3 \mathrm{k}$ & $24.0 \pm 0.5 \mathrm{k}$ \\
\hline 2.d & $7.0 \pm 0.40$ & $11.2 \pm 0.2 \mathrm{mn}$ & $16.9 \pm 0.4 \mathrm{~h}$ & $21.8 \pm 0.4 \mathrm{ef}$ & $23.4 \pm 0.1 \mathrm{k}$ & $25.8 \pm 0.3 j$ & $27.0 . \pm 0.31$ & $27.8 \pm 0.1 \mathrm{hl}$ \\
\hline 3.d & $7.4 \pm 0.10$ & $11.9 \pm 0.3 \mathrm{~lm}$ & $18.5 \pm 0.4 \mathrm{~g}$ & $22.7 \pm 0.7 e$ & $23.7 \pm 0.2 \mathrm{k}$ & $28.2 \pm 0.4 \mathrm{~h}$ & $31.2 \pm 0.5 \mathrm{~g}$ & $34.9 \pm 0.5 f$ \\
\hline 4.d & $7.4 \pm 0.10$ & $12.8 \pm 0.4 \mathrm{kl}$ & $21.4 \pm 0.4 f$ & $25.1 \pm 0.2 d$ & $24.2 \pm 0.4 \mathrm{k}$ & $30.9 \pm 0.4 \mathrm{~g}$ & $37.0 \pm 0.5 e$ & $48.5 \pm 0.6 d$ \\
\hline 5.d & $7.1 \pm 0.50$ & $13.4 \pm 0.5 \mathrm{jk}$ & $24.5 \pm 0.5 d$ & $26.6 \pm 0.5 b c$ & $24.2 \pm 0.9 \mathrm{k}$ & $49.1 \pm 0.2 d$ & $53.9 \pm 0.4 c$ & $54.6 \pm 0.4 \mathrm{c}$ \\
\hline 6.d & $7.6 \pm 0.20$ & $14.6 \pm 0.6 \mathrm{Ij}$ & $25.6 \pm 0.7 \mathrm{~cd}$ & $27.7 \pm 0.5 b$ & $24.1 \pm 0.4 \mathrm{k}$ & $54.9 \pm 0.3 c$ & $58.2 \pm 0.4 b$ & $60.2 \pm 0.3 a$ \\
\hline 7.d & $7.4 \pm 0.20$ & $16.8 \pm 0.6 h$ & $27.7 \pm 0.6 b$ & $30.2 \pm 0.4 a$ & $23.4 \pm 0.6 \mathrm{k}$ & $59.2 \pm 0.3 a b$ & $59.6 \pm 0.6 a$ & $59.4 \pm 0.4 a$ \\
\hline
\end{tabular}

**: The differences among the means without common letter are significant $(p<0.01)$; s. t: sampling time; d: day

Table 3: Descriptive statistics related to the effect of sorbitol ( $g / l)$ and sampling time (day) on caffeic acid $(\mu \mathrm{g} / \mathrm{g})$ and alkamide $(\mu \mathrm{g} / \mathrm{g})$ accumulation in cell suspension cultures of Echinacea purpurea species.

\begin{tabular}{|c|c|c|c|c|c|c|c|c|}
\hline \multirow{2}{*}{ s.t. } & \multicolumn{7}{|c|}{ Sorbitol $(\mathbf{g} / \mathbf{l})$} \\
\cline { 2 - 9 } & \multicolumn{3}{|c|}{ Caffeic acid $(\boldsymbol{\mu g} / \mathbf{g})$} & \multicolumn{4}{c|}{ Alkamide $(\boldsymbol{\mu g} / \mathbf{g})$} \\
\cline { 2 - 9 } & $\mathbf{0}$ & $\mathbf{5}$ & $\mathbf{2 5}$ & $\mathbf{5 0}$ & $\mathbf{0}$ & $\mathbf{5}$ & $\mathbf{2 5}$ & $\mathbf{5 0}$ \\
\hline 1.d & $6.80 \pm 0.3 \mathrm{p}^{* *}$ & $7.56 \pm 0.1 \mathrm{op}$ & $8.51 \pm 0.2 \mathrm{n}$ & $10.8 \pm 0.3 \mathrm{kl}$ & $23.4 \pm 0.1 \mathrm{n}^{* *}$ & $25.4 \pm 0.2 \mathrm{kl}$ & $26.1 \pm 0.1 \mathrm{jk}$ & $26.8 \pm 0.1 \mathrm{j}$ \\
\hline $2 . \mathrm{d}$ & $7.0 \pm 0.4 \mathrm{p}$ & $8.1 \pm 0.3 \mathrm{no}$ & $10.5 \pm 0.1 \mathrm{kl}$ & $13.9 \pm 0.3 \mathrm{hl}$ & $23.4 \pm 0.1 \mathrm{n}$ & $35.7 \pm 0.9 \mathrm{f}$ & $37.6 \pm 0.4 \mathrm{e}$ & $30.7 \pm 0.4 \mathrm{~g}$ \\
\hline 3.d & $7.4 \pm 0.1 \mathrm{op}$ & $9.5 \pm 0.2 \mathrm{~m}$ & $12.1 \pm 0.4 \mathrm{j}$ & $17.7 \pm 0.2 \mathrm{ef}$ & $23.7 \pm 0.1 \mathrm{n}$ & $38.8 \pm 0.7 \mathrm{~d}$ & $42.7 \pm 0.2 \mathrm{a}$ & $29.4 \pm 0.4 \mathrm{~h}$ \\
\hline $4 . \mathrm{d}$ & $7.4 \pm 0.1 \mathrm{op}$ & $10.3 \pm 0.2 \mathrm{~lm}$ & $18.3 \pm 0.2 \mathrm{l}$ & $18.3 \pm 0.3 \mathrm{e}$ & $24.2 \pm 0.4 \mathrm{mn}$ & $39.0 \pm 0.6 \mathrm{~d}$ & $40.7 \pm 0.3 \mathrm{c}$ & $28.1 \pm 0.1 \mathrm{l}$ \\
\hline $5 . \mathrm{d}$ & $7.1 \pm 0.5 \mathrm{p}$ & $11.2 \pm 0.2 \mathrm{k}$ & $15.9 \pm 0.1 \mathrm{~g}$ & $19.9 \pm 0.4 \mathrm{~d}$ & $24.2 \pm 0.1 \mathrm{mn}$ & $40.9 \pm 0.5 \mathrm{bc}$ & $41.0 \pm 0.2 \mathrm{bc}$ & $25.4 \pm 0.1 \mathrm{kl}$ \\
\hline 6.d & $7.6 \pm 0.2 \mathrm{op}$ & $12.1 \pm 0.2 \mathrm{j}$ & $17.2 \pm 0.1 \mathrm{f}$ & $22.4 \pm 0.4 \mathrm{c}$ & $24.1 \pm 0.4 \mathrm{mn}$ & $40.8 \pm 0.3 \mathrm{c}$ & $41.1 \pm 0.3 \mathrm{bc}$ & $24.9 \pm 0.4 \mathrm{~lm}$ \\
\hline $7 . \mathrm{d}$ & $7.4 \pm 0.2 \mathrm{op}$ & $14.4 \pm 0.6 \mathrm{~h}$ & $25.5 \pm 0.5 \mathrm{a}$ & $24.4 \pm 0.2 \mathrm{~b}$ & $23.4 \pm 0.6 \mathrm{n}$ & $41.5 \pm 0.3 \mathrm{bc}$ & $41.9 \pm 0.3 \mathrm{ab}$ & $25.0 \pm 0.5 \mathrm{~lm}$ \\
\hline
\end{tabular}

$* *$ : The differences among the means without common letter are significant $(p<0.01) ; \mathrm{s}$. t: sampling time; d: day 


\begin{tabular}{|c|c|c|c|c|c|c|c|c|}
\hline \multirow{3}{*}{ s.t } & \multicolumn{8}{|c|}{ Cadmium chloride $(\mu \mathrm{M})$} \\
\hline & \multicolumn{4}{|c|}{ Caffeic acid $(\mu \mathrm{g} / \mathrm{g})$} & \multicolumn{4}{|c|}{ Alkamide $(\mu \mathrm{g} / \mathrm{g})$} \\
\hline & 0 & 5 & 25 & 50 & 0 & 5 & 25 & 50 \\
\hline 1.d & $6.8 \pm 0,26 \mathrm{~g}^{* *}$ & $11.3 \pm 0,32 f$ & $16.5 \pm 0,35 \mathrm{e}$ & $17.9 \pm 0,26 f$ & $23.4 \pm 0,10 \mathrm{~h}$ & $86.5 \pm 0,46 e$ & $105 \pm 0,41 a$ & $79 \pm 0,13 f$ \\
\hline 2.d & $7.0 \pm 0,36 \mathrm{~g}$ & $17.4 \pm 0,20 \mathrm{de}$ & $24.7 \pm 0,60 \mathrm{~b}$ & $26.0 \pm 0,21 a$ & $23.4 \pm 0,14 \mathrm{~h}$ & $94.4 \pm 1,14 d$ & $97 \pm 0,13 c$ & $77 \pm 0,44 \mathrm{~g}$ \\
\hline 3.d & $7.4 \pm 0,1 \mathrm{~g}$ & $18.9 \pm 0,13 c$ & $27.0 \pm 0,33 a$ & $26.6 \pm 0,46 a$ & $23.7 \pm 0,14 \mathrm{~h}$ & $94.3 \pm 0,36 d$ & $99 \pm 0,32 b$ & $77 \pm 0,44 \mathrm{~g}$ \\
\hline
\end{tabular}

**: The differences among the means without common letter are significant $(p<0.01)$; s.t: sampling time; d: day

Table 5: Descriptive statistics related to the effect of silver nitrate ( $\mu \mathrm{M})$ and sampling time (day) on caffeic acid $(\mu \mathrm{g} / \mathrm{g})$ and alkamide $(\mu \mathrm{g} / \mathrm{g})$ accumulation in cell suspension cultures of Echinacea purpurea species.

\begin{tabular}{ccccccccc} 
& \multicolumn{9}{c}{ Silver nitrate $(\boldsymbol{\mu M})$} \\
\cline { 2 - 9 } s.t. & \multicolumn{9}{c}{ Caffeic acid $(\boldsymbol{\mu g} / \mathbf{g})$} & & \multicolumn{2}{c}{ Alkamide $(\boldsymbol{\mu g} / \mathbf{g})$} \\
\cline { 2 - 9 } & $\mathbf{0}$ & $\mathbf{5}$ & $\mathbf{2 5}$ & $\mathbf{5 0}$ & $\mathbf{0}$ & $\mathbf{5}$ & $\mathbf{2 5}$ & $\mathbf{5 0}$ \\
\hline 1.d & $6,8 \pm 0,26 \mathrm{n}^{* *}$ & $11.8 \pm 0.150 \mathrm{~g}$ & $15.4 \pm 0.261 \mathrm{f}$ & $15.7 \pm 0.640 \mathrm{f}$ & $23.4 \pm 0,1 \mathrm{~h}^{* *}$ & $96.2 \pm 0,64 \mathrm{~g}$ & $105 \pm 1,0 \mathrm{~d}$ & $127 \pm 0,50 \mathrm{a}$ \\
\hline 2.d & $7,0 \pm 0,36 \mathrm{mn}$ & $17.2 \pm 0.480 \mathrm{e}$ & $25.1 \pm 0.492 \mathrm{c}$ & $25.6 \pm 0.484 \mathrm{c}$ & $23.4 \pm 0,14 \mathrm{~h}$ & $97.6 \pm 0,42 \mathrm{fg}$ & $109 \pm 0,82 \mathrm{c}$ & $104 \pm 0,90 \mathrm{~d}$ \\
\hline $3 . \mathrm{d}$ & $7,4 \pm 0,10 \mathrm{lmn}$ & $20.1 \pm 0.303 \mathrm{~d}$ & $28.9 \pm 0.308 \mathrm{~b}$ & $38.0 \pm 0.260 \mathrm{a}$ & $23.7 \pm 0,14 \mathrm{~h}$ & $98.7 \pm 0,46 \mathrm{f}$ & $115 \pm 1,31 \mathrm{~b}$ & $101 \pm 0,19 \mathrm{e}$ \\
\hline
\end{tabular}

**: The differences among the means without common letter are significant $(p<0.01)$; s. t: sampling time; d: day

dose of $50 \mathrm{mg} / \mathrm{l}$ of yeast extract was much more effective. There have been several studies reporting that the elicitors of chitosan, sorbitol, cadmium chloride and silver nitrate in cell suspension cultures increased plant resistance and induced the activity of phenylalanine ammonium liyaz (PAL). ${ }^{14-18}$ The findings of this present study also support the previous studies, revealing that biotic and abiotic elicitors increase the accumulation of caffeic acid and alkamide. In previous studies carried out in Echinacea purpurea species, root hair cultures were used and higher caffeic acid and alkamide accumulation were obtained, compared to our study. In the previous studies, root hair cultures were used whereas stem cells were used in our study. This differences in cell culture may cause different responses to elicitors and the synthesis of phytochemicals in different amounts. ${ }^{19-22}$

\section{CONCLUSION}

In general, several studies related to increasing the amount of caffeic acid and alkamide have been carried out on Echinacea species. These studies have indicated that root hair cultures are successful in increasing caffeic acid and alkamide accumulation. In this study using stem cell culture, it was also revealed that the accumulation of caffeic acid and alkamide could increase with certain elicitors applied to cell suspension cultures of Echinacea purpurea species.

\section{ACKNOWLEDGEMENT}

We are thankful to Scientific Research Projects Unit (BAP) of Ordu University for providing financial support to this research, with the number of AR-1340 BAP Project.

\section{CONFLICT OF INTEREST}

The authors have no conflict of interest

\section{ABBREVIATION}

dw: dry weight; s. t: sampling time; d: day; $\mu \mathrm{g}$ : microgram; $\mu \mathbf{M}$ : micro molar; GC-MS: Gases Chromatography-Mass Spectrometer; U. V: ultraviolet light; MS: Murashige and Skoog; B5: Gamborg; BAP: benzyladenine; 2,4-D: 2,4-diklorofenoksi acetic acid; IBA: indol3-butirik acid; $\mathbf{G A}_{3}$ : gibberellic acid; NAA: naftalinacetic acid; KIN: kinetin; $\mathbf{C d C I}_{2}$ : cadmium klorit; $\mathbf{A g N O}_{3}$ : silver nitrate.

\section{REFERENCES}

1. Xu CG, Tang TX, Chen R, Liang CH, Liu XY, Wu CL, et al. A comparative study of bioactive secondary metabolite production in diploid and tetraploid Echinacea purpurea (L.) Moench. Plant Cell, Tissue and Organ Culture (PCTOC). 2014;116(3):323-32.

2. Manayi A, Mahdi V, Soodabeh S. Echinacea purpurea: Pharmacology, phytochemistry and analysis methods. Pharmacognosy reviews. 2015;9(17):63.

3. El-Aal MSA, Rabie KAE, Hossam HM. The Effect of UV-C on Secondary Metabolites Productıon of Echinacea purpurea Culture in vitro. Environmental Science and Technology. 2016;11(2):465-83. 
4. Liu R, Li W, Sun LY, Liu CZ. Improving root growth and cichoric acid derivatives production in hairy root culture of Echinacea purpurea by ultrasound treatment. Biochemical engineering journal. 2012;60:62-6.

5. Wu CH, Murthy HN, Hahn EJ, Paek KY. Large-scale cultivation of adventitious roots of Echinacea purpurea in airlift bioreactors to produce chichoric acid, chlorogenic acid and caftaric acid. Biotechnology letters. 2007;29(8):1179-82.

6. Romero FR, Delate K, Kraus GA, Solco AK, Murphy PA, Hannapel DJ. Alkamide production from hairy root cultures of Echinacea. in vitro Cellular and Developmental Biology-Plant. 2009;45(5):599.

7. Sabra A, Adam L, Daayf F, Renault S. Salinity-induced changes in caffeic acid derivatives, alkamide and ketones in three Echinacea species. Environmental and experimental botany. 2012;77:234-41.

8. Gualandi RJ, Augé RM, Kopsell DA, Ownley BH, Chen F, Toler HD, et al. Fungal mutualists enhance growth and phytochemical content in Echinacea purpurea. Symbiosis. 2014;63(3):111-21.

9. Murthy HN, Kim YS, Park SY, Paek KY. Biotechnological production of caffeic acid derivatives from cell and organ cultures of Echinacea species. Applied microbiology and biotechnology. 2014;98(18):7707-17.

10. Ge X, Wu J. Tanshinone production and isoprenoid pathways in Salvia miltiorrhiza hairy roots induced by $\mathrm{Ag}+$ and yeast elicitor. Plant Science. 2005;168(2):487-91.

11. Zhao JL, Zhou LG, Wu JY. Effects of biotic and abiotic elicitors on cell growth and tanshinone accumulation in Salvia miltiorrhiza cell cultures. Applied Microbiology and Biotechnology. 2010;87(1):137-44.

12. Zaker A, Sykora C, Gössnitzer F, Abrishamchi P, Asili J, Mousavi SH, et al. Effects of some elicitors on tanshinone production in adventitious root cultures of Perovskia abrotanoides Karel. Industrial Crops and Products. 2015;67:97-102.

13. Kochan E, Szymczyk P, Kuźma Ł, Lipert A, Szymańska G. Yeast Extract Stimulates Ginsenoside Production in Hairy Root Cultures of American Ginseng Cultivated in Shake Flasks and Nutrient Sprinkle Bioreactors. Molecules. 2017;22(6):880.

14. Kumari P, Kumar A, Priyadarshni M, Kumari R, Shukla LN. Impact of different growth regulators supplemented in MS medium on induction of callus from leaf explants of natural sweetener, Stevia rebaudiana (Bertoni). International Journal of Research in Biosciences. 2017;6(1):14-8.

15. Shi M, Kwork KW, Wu JY. Enhancement of tanshinone production in Salvia miltiorrhiza Bunge (red or Chinese sage) hairy-root culture by hyperosmotic stress and yeast elicitor. Biotechnology and Applied Biochemistry. 2007;46(4):191-6.

16. Li B, Wang B, Li H, Peng L, Ru M, Liang Z, et al. Establishment of Salvia castanea Diels $f$. tomentosa Stib. Hairy root cultures and the promotion of tanshinone accumulation and gene expression with $\mathrm{Ag}+$, methyl jasmonate, and yeast extract elicitation. Protoplasma. 2015;253(1):87-100.

17. Sarropoulou V, Maloupa E. Effect of the NO donor "sodium nitroprusside" (SNP), the ethylene inhibitor "cobalt chloride" $\left(\mathrm{CoCl}_{2}\right)$ and the antioxidant vitamin E "a-tocopherol" on in vitro shoot proliferation of Sideritis raeseri Boiss and Heldr. Subsp. raeseri. Plant Cell, Tissue and Organ Culture (PCTOC). 2017;128(3):619-29.

18. Cai Z, Kastell A, Speiser C, Smetanska I. Enhanced resveratrol production in Vitis vinifera cell suspension cultures by heavy metals without loss of cell viability. Applied Biochemistry and Biotechnology. 2013;171(2):330-40.

19. Chodisetti B, Rao K, Gandi S, Giri A. Gymnemic acid enhancement in the suspension cultures of Gymnema sylvestre by using the signaling moleculesmethyl jasmonate and salicylic acid. in vitro Cellular and Developmental Biology-Plant. 2015;51(1):88-92.

20. Hashemi SM, Naghavi MR. Production and gene expression of morphinan alkaloids in hairy root culture of Papaver orientale L. using abiotic elicitors. Plant Cell, Tissue Organ Culture. 2016;125(1):31-41.

21. Gezici S, Sekeroglu N. Regulation of MicroRNAs By Natural Products and Bioactive Compounds Obtained from Common Medicinal Plants: Novel Strategy in Cancer Therapy. Indian Journal of Pharmaceutical Education and Research (IJPER). 2017;51(3):S483-S8.

22. Chu M, Pedreño MA, Alburquerque N, Faize L, Burgos L, Almagro L. A new strategy to enhance the biosynthesis of trans-resveratrol by overexpressing stilbene synthase gene in elicited Vitis vinifera cell cultures. Plant Physiology and Biochemistry. 2017;113:141-8.

\section{PICTORIAL ABSTRACT}

Bioactive compounds called secondary metabolites are of considerable importance in plant survival and human health

Biotic and abiotic elicitors are used to create stress conditions to induce the synthesis of secondary metabolites, by driving cell defense systems

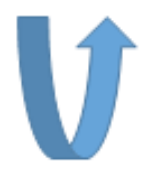

As compared to the initial culture, alkamide and caffeic acid content increased using biotic and abiotic elicitors in purple coneflower.

\section{About Authors}

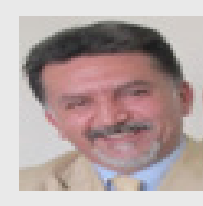

Prof. Dr. Sevket Metin Kara: He is the professor of department of Field Crops of Agricultural Faculty, Ordu University. His area of research is oil crops and medicinal and aromatic plants. He has more than 20 years of teaching and research experience in Field Crops.

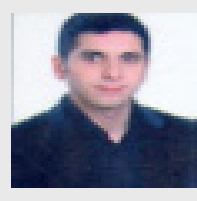

Muhammed Akif Açıkgoz: He is the doctor of department of Field Crops of Agricultural Faculty, Ordu University of Turkey. His research areas include plant biotechnology, tissue culture, volatile oils and secondary metabolites in medicinal and aromatic plants. 


\section{SUMMARY}

- Producing secondary metabolites using biotic and abiotic elicitors in vitro has recently become important worldwide.

- The cell suspension cultures were subjected to biotic (chitosan and yeast extract) and abiotic (cadmium chloride, silver nitrate and sorbitol) elicitors to increase accumulation of caffeik acid and alkamide.

- All biotic and abiotic elicitors increased the content of alkamide and caffeik acid.

- Biotic and abiotic elicitors showed a great potential for increasing alkamide and caffeic acid in purple coneflower.

Cite this article: Açikgöz MA, Yarilgaç T, Kara SM. Enhancement of Phytochemical Compounds Using Biotic and Abiotic Elicitors in Purple Coneflower (Echinacea purpurea L.). Indian J of Pharmaceutical Education and Research. 2018;52(4S):S140-S145. 